\title{
PENGGUNAAN KONTRAS WARNA DALAM FOTOGRAFI
}

\author{
John Felix \\ Jurusan Desain Komunikasi Visual, Fakultas Komunikasi dan Multimedia, \\ Bina Nusantara Universiy, Jln. K.H. Syahdan No. 9, Kemanggisan Jakarta Barat \\ jtubagus@binus.edu
}

\begin{abstract}
Photography now is a science that attract many people from those who learn it jus for hobby or those who wish to enter the industry. Since human found a way to record colors in photographic meaning, photographers face a new challenge on how to compose colors and what is the effect of using the chosen color. This article explain how to apply colors not just as a way to make a photograph looks as what human sees but also as a visual element to give an emphasis to the main subject and still looks comfortable to the eye of the viewer.
\end{abstract}

Keywords: photography, color, composition, visual element

\begin{abstract}
ABSTRAK
Fotografi saat ini adalah sebuah ilmu yang semakin diminati oleh banyak orang. Baik dari yang sekadar untuk hobi sampai yang mempelajarinya karena ingin ikut terjun ke dunia industri. Semenjak ditemukan cara untuk merekam warna ke dalam sebuah gambar foto maka tantangan untuk memproduksi sebuah karya fotografi semakin bertambah karena disamping harus memikirkan pencahayaan maka seorang fotografer juga harus memikirkan tentang komposisi warna dan efek yang dihasilkan oleh penggunaan warna yang dipilih. Artikel ini menjelaskan tentang pemakian warna dalam karya fotografi sebagai elemen visual yang tidak hanya untuk membuat sebuah gambar foto terlihat menjadi seperti yang dilihat oleh mata manusia, tetapi juga mampu membuat foto tersebut terlihat menarik, berbeda, dan nyaman dilihat, jika elemen visual ini digunakan dengan benar.
\end{abstract}

Kata kunci: fotografi, warna, komposisi, elemen visual 


\section{PENDAHULUAN}

Sejak jaman dahulu, jauh sebelum tulisan ada, manusia telah menunjukan keinginan yang besar untuk mengkomunikasikan sesuatu melalui visual.Mulai dari gambar - gambar di gua yang terbentang dari Lascaux hingga Leang - Leang, semuanya adalah bukti bahwa manusia berusaha meninggalkan jejaknya dalam peradaban dengan mengawetkan eksistensi mereka dalam sebuah rekaman visual. Seiring berjalannya waktu manusia menemukan cara - cara baru sebagai media untuk merekam dan mengkomunikasikan pesan visual mereka. Salah satu dari media komunikasi tersebut adalah fotografi, penemuan yang berasal dari abad 19 yang mempunyai pengaruh besar bagi peradaban umat manusia. Penemuan ini memungkinkan manusia untuk merekam data visual dengan lebih akurat dibandingkan dengan sketsa atau gambar. Fotografi juga memungkinkan manusia untuk menyaksikan keadaan di suatu tempat dengan lebih nyata. Seluruh emosi, ekspresi, momen, dan objek terekam dan terawetkan untuk dilihat dan dipelajari oleh generasi - generasi selanjutnya.

Dalam perjalanannya, fotografi mengalami perkembangan, mulai dari media yang hanya mampu merekam cahaya, sehingga menghasilkan foto hitam putih, hingga ke media yang mampu merekam warna, sehingga lengkap sudah kemampuan Fotografi sebagai media pengganti gambar tangan untuk merekam informasi visual. Dimata para seniman foto, Warna menjadi elemen penting yang, jika digunakan dengan tepat, akan menghasilkan foto yang baik dan menarik.

\section{PEMBAHASAN}

Fotografi adalah media yang tidak ditemukan dalam sekali percobaan, melainkan kumpulan dari serangkaian percobaan yang kemudian dikombinasikan sehingga saling melengkapi. Ide tentang cahaya yang masuk ke dalam sebuah ruang kedap cahaya melalui sebuah lubang kecil akan menghasilkan gambar dari objek yang ada di depan ruang tersebut, telah ada sejak sekitar jaman Aristoteles. Ide ini kemudian dibuktikan oleh seorang cendekiawan dari Arab bernama Alhazen yang dikenal juga sebagai Ibn Al Haytham yang mejelaskan bagaimana cara melihat Gerhana matahari melalui sebuah alat yang disebut kamera Obscura (yang artinya 'Ruang Gelap”). Sekalipun kamera ini adalah cikal bakal dari kamera - kamera modern saat ini, namun pada awal penggunaannya, kamera Obscura hanya diakai sebagai alat bantu untuk membuat gambar. Alat ini memungkinkan seniman untuk menjiplak (mentracing) gambar yang dipantulkan di atas bidang kertas. Pada Jaman ini kamera Obscura mempunyai ukuran yang mencapai ukuran sebuah ruangan yang bisa dimasuki oleh manusia, kemudian pada jaman Renaisans kamera ini dibuat menjadi seukuran kotak kecil yang bisa dibawa dengan tangan dan di depan lubang ditambahkan lensa untuk memperbaiki kualitas gambar.

Fungsi kamera Obscura bergeser menjadi alat perekam cahaya, baru terjadi pada saat Joseph Nicephore Niepce, seorang penemu berkebangsaan Prancis menemukan Heliograph, sebuah nama yang berasal dari bahasa yunani yang secara harfiah berarti menggambar dengan matahari.Proses ini adalah sebuah proses untuk merekam cahaya pada media yang disebut Bitumen of Judea, sejenis aspal yang akan mengeras jika terkena cahaya. Niepce melarutkan Bitumen ini ke dalam minyak lavender, kemudian larutan ini dilapis ke permukaan selembar campuran timah. Kemudian lembar tersebut diletakan di dalam kamera Obscura dan diletakan di jendela yang terbuka kea arah halaman gedung. Proses ini memerlukan waktu expose selama delapan jam. Cahaya yang jatuh ke permukaan pelat membuat aspal mengeras sehingga pada saat pelat dicuci dengan minyak lavender dareah yang tidak terkena cahaya akan larut dan hilang tercuci, meninggalkan daerah keras yang membentuk gambar. Gambar ini adalah foto pertama yang berhasil dibuat. 
Apakah sebelum Niepce menemukan Heliograph, tidak ada ilmuwan lain yang berusaha meneliti tentang cara menangkap cahaya? Ternyata ada. Sejak abad 17 manusia telah menemukan bahwa senyawa perak tertentu dapat menghitam saat diekspos pada cahaya. Tetapi masalah yang sulit dipecahkan adalah bagaimana menghentikan proses penghitaman, agar gambar yang direkam tidak menjadi hitam total.

Setelah Heliograph ditemukan, seorang berkebangsaan Prancis yang lain bernama Louis Jaques Mande Daguere mengajak Niepce bekerja sama menyempurnakan Heliograph. Sayangnya Niepce tidak sempat menuntaskan usaha penyempurnaan Heliograph. Dia meninggal di tahun 1833, beberapa tahun sebelum Daguerre yang meneruskan usaha penyempurnaan tersebut mencapai keberhasilan dan menamakan Proses yang disempurnakan ini sebagai Daguerreotype. Pada masa itu teknologi fotografi belum mampu menghasilkan foto dengan warna sehinggasemua hasil foto adalah hitam putih. Manusia baru mengerti tentang cara merekam cahaya tetapi belum mengerti tentang cara merekam warna. Itu sebabnya media fotografi hanya mampu merekam terang dan gelap.Keindahan sebuah karya fotografi hanya dilihat melalui bentuk, kontras dan detail saja. Pada masa itu seniman foto harus bisa menginterpretasikan warna yang ada di lokasi pemotretan menjadi salah satu dari antara warna hitam tanpa detail hingga putih tanpa detail.

Foto berwarna pertama kali hadir pada tahun 1839, melalui teknik Daguerreotype, sebuah teknik yang mampu menghasilkan gambar positif yang diproduksi di atas pelat tembaga yang dilapisi oleh perak dengan tingkat detail yang baik dan setiap foto yang dihasilkan merupakan hasil foto yang tidak dapat diperbanyak, sehingga setiap foto adalah unik. Satu - satunya kekurangan dari teknik ini adalah gambar yang dihasilkan tidak berwarna. Ini memotivasi orang - orang untuk mencari cara untuk mengatasi kekurangan ini. Tidak mengherankan jika pada tahun yang sama fotografi berwarna yang pertama muncul. Pewarnaan pada foto dilakukan langsung pada permukaan Daguerreotype dengan menggunakan tangan. Ada empat metode yang bisa dipakai dalam melakukan pewarnaan Daguerreotype dengan tangan. Dibutuhkan hampir seratus tahun penelitian dan pengembangan untuk bisa menghasilkan foto berwarna yang baik dan dibuat murni melalui jalan fotografi.

\section{Apa Itu Cahaya}

Jika kita diajukan pertanyaan seperti ini, maka kemungkinan kita akan teringat pada pelajaran semasa di sekolah dasar dimana kita diminta untuk mengadakan percobaan dengan melewatkan cahaya matahari melalui sebuah prisma kaca dan menghasilkan warna pelangi yang tercipta dari spectrum cahaya yang diuraikan (merah, Jingga, kuning, hijau, biru, indigo, violet dan warna gradasi diantaranya). Percobaan ini dilakukan pertama kali oleh Isaac Newton untuk membuktikan bahwa warna ada di dalam cahaya dan cahaya yang dilihat oleh manusia sebagai warna putih sebetulnya adalah percampuran dari gelombang spektrum cahaya yang dapat dilihat oleh mata. Prisma yang digunakan oleh Newton memisahkan cahaya yang melewatinya melalui sebuah proses yang disebut refraksi. Proses ini membuat gelombang cahaya dari setiap spektrum warna membelok sehingga terurai satu sama lain. Panjang gelombang dari setiap spektrumlah yang menetukan warna yang terlihat.

Warna dalam cahaya juga bisa dipisahkan oleh permukaan suatu objek. Kenapa bisa seperti itu? Jawabannya adalah karena kita melihat suatu warna pada sebuah objek sebagai hasil pantulan dari cahaya dengan panjang gelombang tertentu dari permukaan objek yang kemudian ditangkap oleh mata kita. Sebagai contoh, mobil berwarna akan terlihat merah karena pada saat mobil terkena cahaya, haya warna merah yang dipantulalkan. Seluruh warna bukan merah yang ada dalam cahaya diserap oleh mobil tersebut. Sehingga satu satunya gelombang cahaya yang sampai ke mata kita adalah gelombang cahaya warna merah, maka kita melihat mobil tersebut berwarna merah. Sedangkan kulit telur terlihat berwarna putih karena kulit telur memantulkan seluruh gelombang cahaya yang datang kepadanya. Jika cahaya dilewatkan melalui sebuah filter dengan warna tertentu, maka cahaya yang telah melewati 
filter akan merubah warna dari objek yang terkena cahaya tersebut. Sebagai contoh jika kulit telur disinari oleh cahaya yang telah melewati filter berwarna merah, maka kulit telur tersebut akan terlihat berwarna merah. Ini terjadi karena hanya gelombang cahaya berwarna merah yang mengenai permukaan kulit telur, shingga akibatnya hanya gelombang cahaya berwarna merah pula yangdipantulkan oleh kulit telur. Objek yang mampu meneruskan cahayaseperti slide fiter untuk lampu sebenarnya mempunyai lapisan kimia yang menyerap gelombang cahaya tertentu dan hanya meneruskan gelombang cahaya yang lain sehingga kita hanya akan melihat warna gelombang cahaya yang diteruskan oleh filter tersebut.

Pada tahun 1807 Thomas Young dan Hermann Von Helmholtz mengeluarkan teori tentang Trichromatic color Vision. Teori ini menyatakan bahwa sebenarnya mata manusia hanya peka terhadap tiga warna dalam cahaya, yaitu merah, hijau, biru. Warna - warna ini disebut warna primer dalam cahaya. Bagaimana dengan warna lain yang dilihat oleh mata manusia? Ternyata warna yang lain bisa didapatkan dengan mencampurkan paling tidak dua warna primer atau lebih. Jika tiga warna primer dicampurkan dalam kadar yang sama maka kita akan mendapatkan cahaya berwarna putih. Teori ini kemudian diaplikasikan kedalam media rekam fotografi. Pada masa awal penggunaannya teori ini diaplikasikan kedalam film warna, yang jika kita iris dan kita perbesar penampangnya maka akan terlihat tiga lapis emulsi yang ditopang oleh acetate base. Setiap lapisan emulsi hanya peka terhadap satu warna. Lapisan paling atas hanya peka terhadap warna biru, lapisan tengah terhadap warna hiajudan bagian bawah terhadap warna merah. Cahaya biru hanya akan terekam pada lapisan emulsi paling atas, sedangakan warna hijau pada emulsi bagian tengahdan warna merah pada emulsi bagian bawah. Warna - warna yang lain akan terbentuk oleh kombinasi ketiga dari dua atau ketiga warna cahaya yang terekam oleh setiap lapisan emulsi, tentu saja dengan kadar kepekatan yang berbeda - beda.

Kamera digital pun menggunkan teknik perekaman dengan warna RGB (red, green, blue) Sensor yang ada di dalam kamera biasanya terdiri dari susunan filter berbentuk kotak yang dinamakan Filter Mosaic, dimana setiap pixel akan dilapisi oleh filter berwarna merah, hijau atau biru.Filter warna ini dibutuhkan karena sensor cahaya mendeteksi intensitas cahaya tanpa mempedulikan panjang gelombangnya sehingga informasi warnanya tidak dapat dideteksi. Filter warna akan menyaring panjang gelombang tertentu dari cahaya sehingga yang akan terekam oleh sensor adalah cahaya dengan warna dan intensitas tertentu. Salah satu filter yang umum diterapkan pada sensor cahaya di kamera digital adalah Bayer Pattern yang ditemukan oleh Dr. Bryce E. Bayer dari Eastman Kodak. Filter ini terdiri dari 25 persen pixel berwarna merah, 25 persen biru, dan 50 persen hijau.

\section{Faktor apa saja yang Berpengaruh pada Foto Warna}

Sebuah karya foto, pada saat dinikmati, harus dilihat sebagai sebuah kesatuan. Tetapi sebetulnya di dalam karya tersebut banyak elemen yang dikomposisikan dan setiap elemen ini mempunyai peran sendiri - sendiri. Seorang Fotografer yang baik harus dapat mengerti karakteristik dari setiap elemen yang ada pada lokasi pemotretan sehingga bisa memanfaatkannya dengan baik. Setelah itu Seorang Fotografer juga harus mengerti apa yang akan dilakukan terhadap hasil foto tersebut setelah proses pemotretan selesai. Apakah foto itu akan melalui tahap editing atau langsung di cetak. Jika harus melalui tahap editing, maka elemen apa saja dalam foto tersebut yang harus di proses untuk penyempurnaan. Pada akhirnya semua elemen itu harus dapat terlihat sebagai kesatuan yang membentuk sebuah karya fotografi yang bisa dinikmati seperti dalam gambar 01. Untuk dapat memahami bagaimana cara mengkomposisikan elemen elemen tersebut maka dalam bab ini akan dibahas beberapa elemen yang merupakan faktor yang akan mempengaruhi warna dalam sebuah karya fotografi. Faktor - faktor tersebut adalah warna pada foto itu sendiri, saturasi, brightness dan kontras.Faktor - faktor ini pasti selalu ada pada setiap foto warna karena segala sesuatu yang mempunyai warna pasti mempunyai tingkat saturasi, brightness dan kontras. Dengan kata lain segala sesuatu yang berwarna akan memiliki ketiga faktor tersebut bagaikan api pasti menghasilkan panas. 
Saturasi adalah tingkat kecemerlangan suatu warna berdasarkan banyaknya tingkat abu -abu. Semakin banyak tingkat abu - abu dalam suatu warna akan mengakibatkan semakin berkurang tingkat saturasinya dan semakin sedikit tingkat abu - abu dalam suatu warna maka akan semakin tinggi tingkat saturasinya sehingga akan menghasilkan gambar dengan warna yang semakin cemerlang. Saturasi yang berlebihan pada sebuah foto akan menghasilkan gambar dengan warna yang tidak alami, sedangkan desaturasi secara total akan menghasilkan foto yang hanya memiliki daerah terang dan gelap (hitam putih).

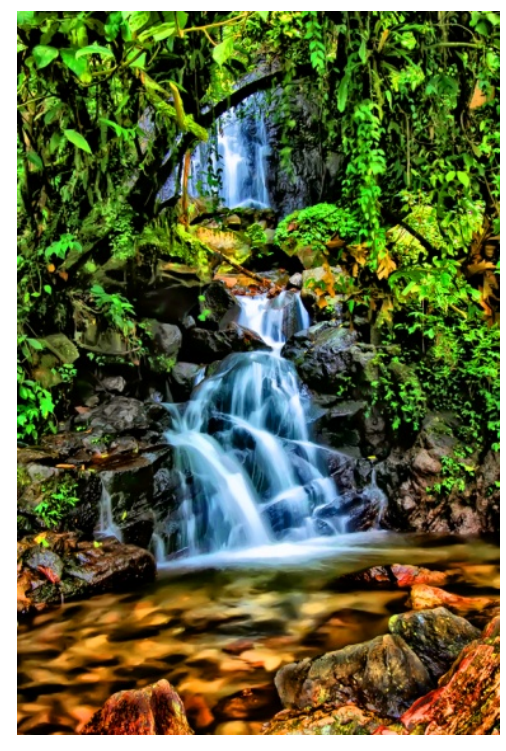

Gambar 1 Foto dengan Tingkat Saturasi Tinggi

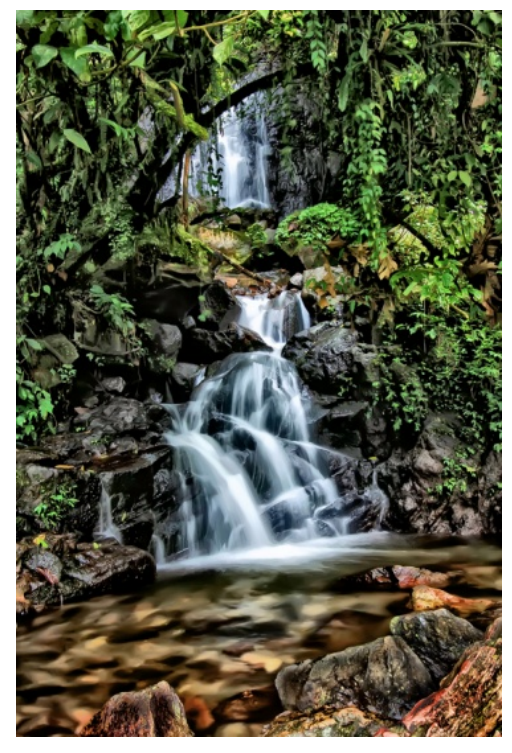

Gambar 2 Foto dengan Saturasi Normal

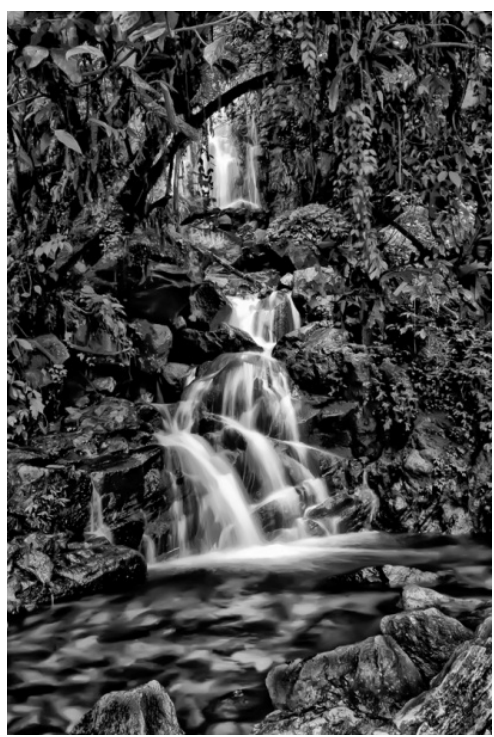

Gambar 3 Foto dengan Tingkat Saturasi vang Dihilangkan Total.

Dalam Gambar 1 terlihat foto yang mempunyai tingkat saturasi sangat tinggi. Warna pada foto begitu cemerlang sehingga foto tersebut terlihat sama sekali tidak alami.Sedangkan pada gambar 2 tingkat saturasinya adalah normal sehingga menghasilkan gambar dengan warna yang cukup mendekati warna asli dari objek. Gambar 3 adalah foto yang sama dengan tingkat saturasi yang dihilangkan secara total, sesuai dengan definisinya maka jika tingkat saturasi dihilangkan maka yang tertinggal hanya abu - abu sehingga foto akan terlihat sebagai foto hitam putih dengan berbagai macam tingkat gradasi abu - abu.

Kontras dalam visual adalah sesuatu yang membuat sebuah objek atau representasi dari objek tersebut dalam bentuk gambar dapat dibedakan dari objek lain atau background. Kontras ditentukan oleh perbedaan dalam warna dan tingkat kecerahan dari objek yang satu dengan yang lainnya dalam jangkauan pandang yang sama. Dalam dunia fotografi, sekalipun foto hitam putih adalah dasar untuk mempelajari fotografi, Sampai pada titik tertentu, semua fotografer harus mempelajari dasar dari foto berwarna. Untuk mempelajari fotografi warna, dibutuhkan pemahaman yang kuat tentang elemen dasar dari fotografi. Salah satu dari elemen tersebut adalah kontras.

Dalam fotografi hitam putih, kontras mengacu pada perbedaan antara daerah yang paling terang dan daerah yang paling gelap dalam sebuah foto itu sebabnya di dalam fotografi hitam putih hanya terdapat tiga jenis kontras tonal yang terdiri dari : high contast, medium contrast dan low contrast. Tetapi dalam fotografi warna hal ini menjadi sedikit lebih rumit karena fotografi warna juga memiliki kontras warna selain dari kontras tonal seperti dalam foto hitam putih.Kontras warna ditentukan melalui bagaimana setiap warna berinteraksi antara satu sama lain.Kontras dalam fotografi 
warna akan sangat efektif untuk digunakan dalam komposisi. Komposisi yang dimaksud di dalam tulisan ini adalah komposisi yang mengarah kepada penyusunan atau pemilihan warna yang akan ditampilkan dalam sebuah foto. Peletakan dan pemilihan warna yang benar antara objek utama dan background serta objek pendukung, akan menghasilkan penekanan tambahan yang akan mengarahkan mata pada pada objek utama.Sebagai contoh jika sebuah kembang berwarna violet diletakan diatas hamparan rumput hijau maka bunga tersebut akan terlihat menonjol karena dengan komposisi warna violet dan warna hijau yang diletakan berdekatan akan mengahsilkan interaksi warna antara satu sama lain sehingga akan membentuk gambar dengan kontras warna yang tinggi. Kontras yang warna tinggi pada gambar akan mengarahkan mata orang yang melihat langsung ke objek utama, dalam hal ini objek utama itu adalah kembang violet.

Dalam memproses foto berwarna, seorang fotografer harus memperhatikan bahwa pada saat kontras diubah maka warna pada foto juga akan berubah, seperti yang diperlihatkan oleh gambar 04 . Pada gambar tersebut terlihat perbedaan warna yang terjadi akibat kontras yang diubah. Gambar di sebelah kiri adalah gambar dengan kontras yang belum diubah. Perhatikan warna pada baju dari objek utama. Pada gambar di sebelah kanan, kontras pada foto telah dinaikan sehingga foto terlihat lebih gelap dan warna pada pakaian terlihat lebih tua.

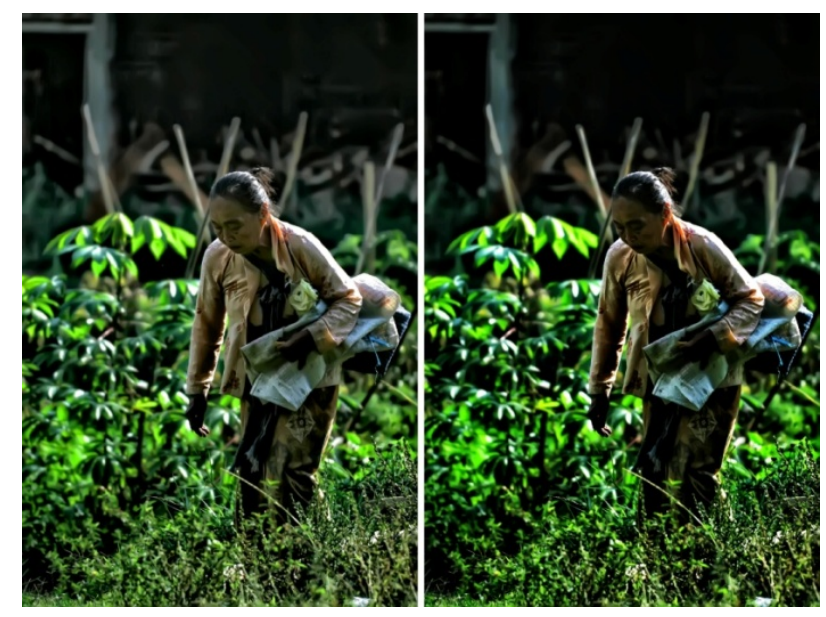

Gambar 4 Perubahan Warna Foto Akibat Perubahan Kontras

Brightness adalah tingkat kecerahan pada sebuah gambar atau foto sesuai dengan yang diinginkan oleh fotografer.Dalam brightness dikenal istilah Under Exposed, Normal Exposed dan Over Exposed. Istilah Under Exposed mengacu pada keadaan diaman foto yang dihasilkan ternyata mempunyai tingkat kecerahan yang lebih redup atau gelap dibandingkan dengan yang terlihat oleh mata. Normal Exposed mengacu pada keadaan dimana foto yang dihasilkan ternyata mempunyai tingkat kecerahan yang sesuai dengan dengan keadan yang dilihat oleh mata. Sedangkan Over Exposed adalah keadaan dimana foto yang dihasilkan ternyata lebih terang dari pada apa yang dilihat oleh mata. Tingkat kecerahan ini ternyata berpengaruh terhadap warna yang akan tampil pada hasil foto. Foto yang tingkat tingkat kecerahannya dibuat over exposed, baik itu dilakukan melalui kamera pada saat pemotretan ataupun melalui software pada saat proses editing akan membuat warna semakin terlihat cerah menuju ke arah putih seperti yang terlihat pada gambar 5. Gambar ini menunjukan perbandingan antara foto dengan tingkat brightness normal pada gambar sebelah kiri dan foto dengan tingkat brightness yang tinggi pada foto sebelah kanan.

Hal yang lain yang perlu diperhatikan, berkaitan dengan brightness adalah semakin tinggi tingkat brightness maka kemungkinan detail dari gambar akan hilang juga semakin besar. Jika diperhatikan dengan baik maka akan terlihat bahwa nasi pada gambar sebelah kanan menjadi berwarna 
putih blok tanpa ada detail yang membentuk bulir - bulir nasi seperti pada gambar sebelah kiri. Hal yang sama juga terjadi pada detail minyak lilin, detail pada gambar tahu, ikan, tepian cobek dan daerah - daerah lain pada gambar yang pada gambar sebelah kiri terlihat normal dan memiliki detail. Keadaan dimana detail dari sebuah gambar menjadi hilang karena tingkat brightness yang terlalu tinggi disebut detail wash out.

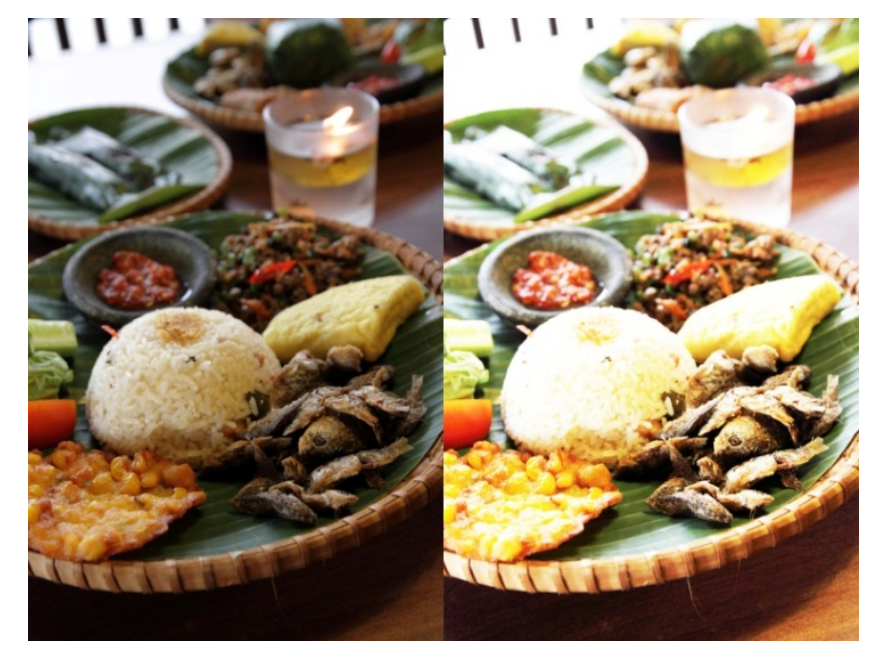

Gambar 5 Foto dengan Tingkat Brightness yang Ditambahkan

Gambar 6 adalah contoh yang memperlihatkan perbandingan antara foto dengan tingkat brightness normal pada gambar sebelah kiri dan foto dengan dengan tingkat brightness yang tinggi pada foto sebelah kanan. Pada foto ini dapat dilihat bahwa dengan menurunkan tingkat brightness, secara keseluruhan foto akan terlihat semakin gelap. Dengan semakin gelap maka warna pada setiap benda yang ada di dalam foto juga akan berubah menjadi lebih tua mengarah ke hitam. Kemudian perhatikan setiap objek yang terdapat pada foto. Bagian yang terlihat normal pada foto di sebelah kiri akan terlihat menjadi lebih gelap namun masih terlihat detailnya pada foto sebelah kanan, sedangkan bagian yang sedikit gelap pada foto sebelah kiri akan terlihat menjadi gelap dan kehilangan detail pada foto sebelah kanan.

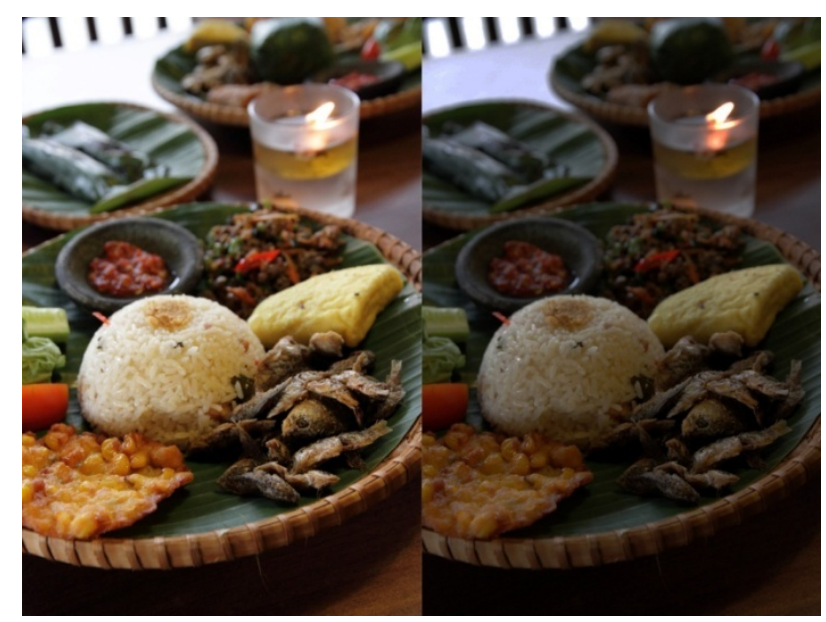

Gambar 6 Foto dengan Tingkat Brightness yang Dikurangi 


\section{Peran Warna Dalam Sebuah Karya Fotografi}

Setelah mengerti tentang faktor - faktor yang berpengaruh dalam sebuah foto berwarna maka akan lebih mudah untuk memahami apa peran warna dalam sebuah karya foto. Berdasarkan kepada faktor faktor yang mempengaruhi warna yang sudah kita bahas di atas, maka dapat disimpulkan bahwa dalam sebuah karya fotografi, warna dapat berperan sebagai salah satu elemen yang dapat membantu memberi penekanan dan mengarahkan mata pemirsa ke objek utama melalui permainan kontras antara objek utama dan objek pendukung serta background.Untuk lebih menjelaskan kesimpulan diatas maka kita bisa menganalisa foto pada gambar 07. Pada gambar 07, objek utama diberikan warna hijau dan biru melalui baju yang dipakai.Dengan memberikan warna yang terlihat cerah seperti ini, akan membuat objek utama terlihat lebih menonjol dibanding sekitarnya yang mempunyai warna cenderung abu - abu dan bernuansa suram.Warna yang cerah dipadukan dengan warna abu - abu yang suram akan menghasilkan kontras yang cukup tinggi. Kontras ini membuat mata orang - orang yang melihat foto tersebut menjadi langsung terarah kepada kedua pekerja di sebelah kanan atas foto yang memang merupakan Point of Interest dari foto tersebut.

Selain menggunakan teknik permainan kontras antara objek utama dan objek pendukung serta background, foto pada gambar 7 juga menggunakan teknik framing. Teknik framing adalah teknik yang mengandalkan objek - objek pendukung yang terdapat di dalam daerah jangkauan viewfinder kamera sebagai bingkai untuk membantu mengarahkan mata ke objek utama. Dalam foto pada gambar 07, objek yang berfungsi sebagai bingkai adalah mesin pada bagian foreground atau latar depan, kemudian tiang baja pada sisi sebelah kiri foto dan reruntuhan gedung yang terdapat pada background atau latar belakang foto.

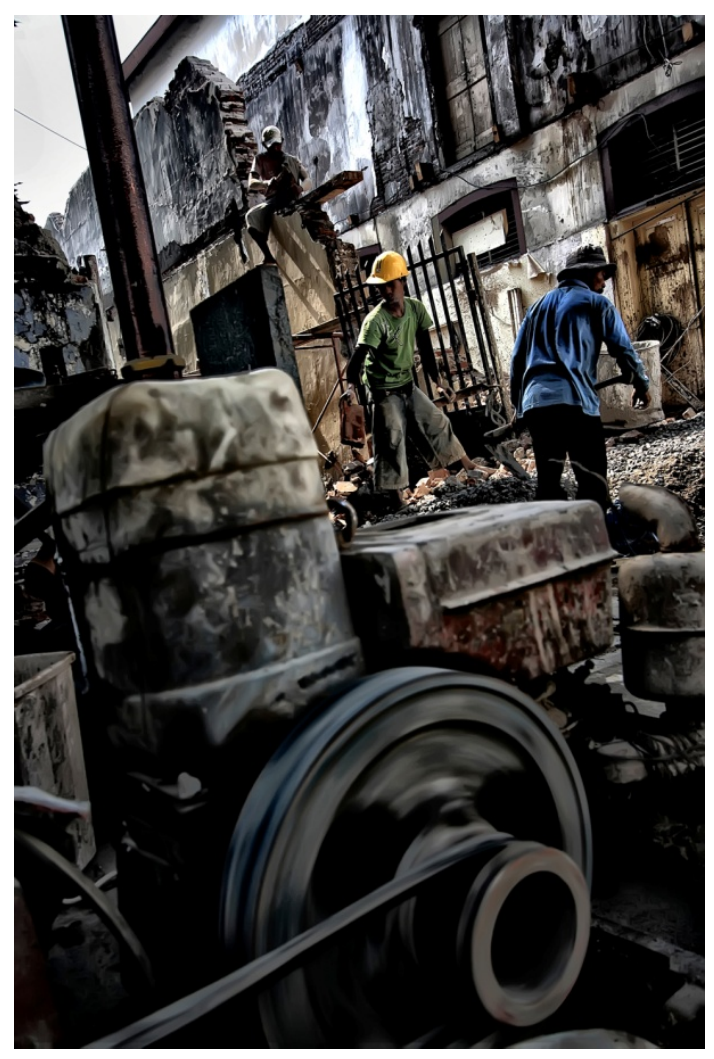

Gambar 7 Foto dengan Teknik Framing 
Warna adalah hal pertama yang dilihat oleh seseorang. Itu sebabnya warna merupakan unsur yang penting dalam sebuah karya fotografi karena warna dapat memberikan dampak psikologis kepada orang yang melihat. Warna juga mampu memberikan sugesti yang mendalam kepada manusia. Selain menggunakan kontras yang terdapat pada warna, seorang fotografer juga bisa menggunakan kombinasi antara warna - warna yang disebut warna dingin dan warna hangat untuk mengarahkan mata orang yang melihat sebuah foto menuju objek utama. Apa arti dari terminologi warna dingin dan warna hangat?

Ternyata terminologi warna dingin dan warna hangatsebenarnya berhubungan dengan persepsi dan reaksi psikologis seseorang terhadap warna. Warna -warna yang dianggap warna hangat cenderung merangsang dan menstimulasi orang yang melihatnya. Sedangkan warna - warna yang dianggap warna dingin cenderung membuat orang yang melihatnya merasa tenang dan santai.Warna warna yang secara umum dianggap sebagai warna hangat adalah warna merah hingga kuning.Warna coklat juga termasuk warna yang dianggap hangat. Sedangkan warna - warna yang secara umum dianggap sebagai warna dingin adalahwarna biru, hijau, violet dan beberapa warna abu - abu.Biasanya warna - warna yang dianggap hangat akan terlihat lebih menonjol jika dibandingkan dengan warna warna yang dianggap dingin, saat kedua warna tersebut digunakan pada sebuah karya foto pada saat bersamaan. Untuk bisa lebih memahami bagaimana kombinasi warna hangat dan dingin bisa mengarahkan mataorang yang melihat sebuah foto, langsung menuju ke objek utama, maka kita akan menganalisa contoh foto pada gambar 8 .

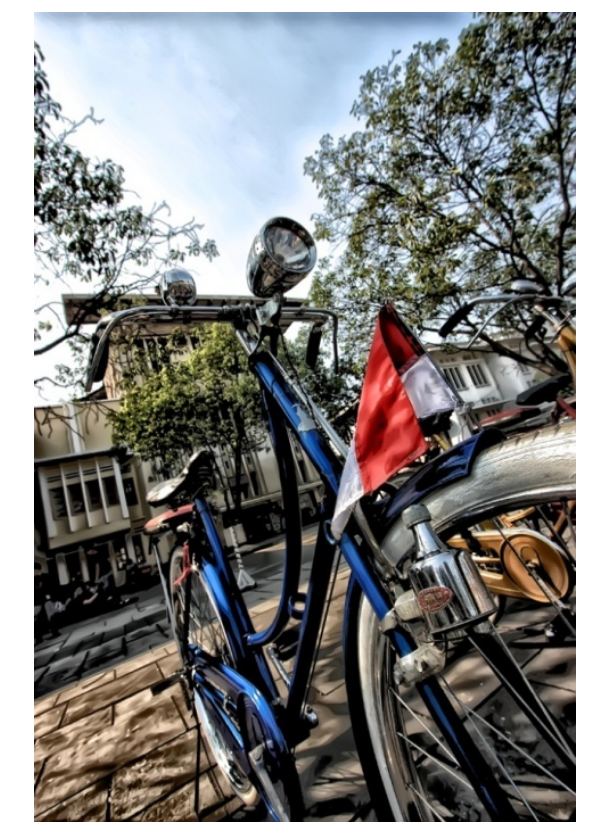

Gambar 8 Kombinasi Warna Hangat dan Dingin dalam Foto

Pada saat seseorang melihat foto pada gambar 08, pada umumnya mata orang itu akan langsung terarah pada bendera yang terdapat di bagian depan sepeda. Hal ini terjadi karena background pada foto tersebut sebagian besar adalah warna - warna yang mempunyai karakter dingin seperti warna biru pada langit, pada sepeda serta warna hijau pada daun dan beberapa warna netral seperti putih pada langit dan krem pada bangunan, sementara pada bagian depan dari sepeda terdapat bendera dengan warna yang sebagian besar adalah merah. Dalam lingkaran warna, merah adalah warna paling panas dan memiliki gelombang warna paling panjang sehingga warna inilah yang paling cepat tertangkap oleh mata. 


\section{SIMPULAN}

Sejak ditemukan cara merekam warna ke dalam media fotografi, maka proses pembuatan sebuah karya fotografi harus memikirkan tentang komposisi dan efek dari penggunaan warna yang dipilih. Jika ini dilakukan dengan benar maka warna yang difungsikan sebagai elemen visual akan mampu membuat penekanan kepada objek utama dari foto. Hal ini akan membantu mengarahkan mata orang yang melihat karya foto langsung menuju ke objek utama. Cara yang bisa dilakukan untuk mengaplikasikan penekanan kepada objek utama melalui warna adalah dengan memainkan kontras warna antara objek utama dan objek pendukung serta background. Warna - warna yang termasuk ke dalam kategori warna hangat akan terlihat lebih menonjol jika dikomposisikan bersama dengan warna - warna yang termasuk ke dalam warna dingin.

\section{DAFTAR PUSTAKA}

Hirch, R. (2005). Exploring Colour Photography, London: Laurence King Publishing Ltd.

London, B., Upton, J., Stone, J., Kobre, K. (2005). Photography, $5^{\text {th }}$ Edition, New Jersey: Pearson Education, Inc

Meggs, P. B., \& Purvis, A. W. (2006). Meggs' History of Graphic Design, $4^{\text {th }}$ Edition, New Jersey: John Wiley \& Sons, Inc 